Bedankt voor het downloaden van dit artikel. De artikelen uit de (online)tijdschriften van Uitgeverij Boom zijn auteursrechtelijk beschermd. U kunt er natuurlijk uit citeren (voorzien van een bronvermelding) maar voor reproductie in welke vorm dan ook moet toestemming aan de uitgever worden gevraagd.

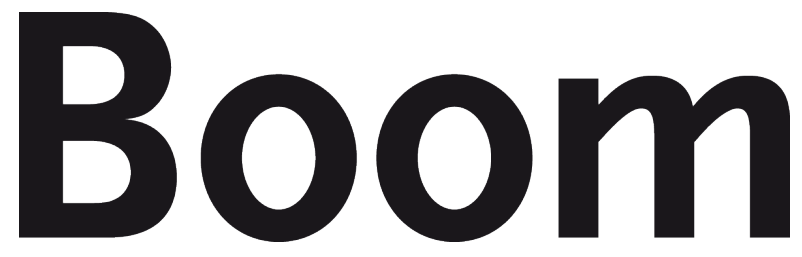

Behoudens de in of krachtens de Auteurswet van 1912 gestelde uitzonderingen mag niets uit deze uitgave worden verveelvoudigd, opgeslagen in een geautomatiseerd gegevensbestand, of openbaar gemaakt, in enige vorm of op enige wijze, hetzij elektronisch, mechanisch door fotokopieën, opnamen of enig andere manier, zonder voorafgaande schriftelijke toestemming van de uitgever.

Voor zover het maken van kopieën uit deze uitgave is toegestaan op grond van artikelen $16 \mathrm{~h} \mathrm{t} / \mathrm{m} \mathrm{16m}$ Auteurswet 1912 jo. Besluit van 27 november 2002, Stb 575, dient men de daarvoor wettelijk verschuldigde vergoeding te voldoen aan de Stichting Reprorecht te Hoofddorp (postbus 3060, 2130 KB, www.reprorecht.nl) of contact op te nemen met de uitgever voor het treffen van een rechtstreekse regeling in de zin van art. 16l, vijfde lid, Auteurswet 1912.

Voor het overnemen van gedeelte(n) uit deze uitgave in bloemlezingen, readers en andere compilatiewerken (artikel 16, Auteurswet 1912) kan men zich wenden tot de Stichting PRO (Stichting Publicatie- en Reproductierechten, postbus 3060, 2130 KB Hoofddorp, www.cedar.nl/pro).

No part of this book may be reproduced in any way whatsoever without the written permission of the publisher.

info@boomamsterdam.nl www.boomuitgeversamsterdam.nl 


\title{
Methodological passages to Digital Humanities
}

\author{
Rianne Dekker*
}

K. Leurs, Digital passages: Migrant youth 2.0. Diaspora, gender and youth cultural intersections, Amsterdam: Amsterdam University Press, 2015, 324 pp., ISBN 978-90896-4640-8, € 39,95 (pbk). Available at (open access): www.oapen.org/search?identifier $=559550$.

The latest edition to AUP's MediaMatters series on media technology and practices is Koen Leurs' Digital Passages. In this book, Leurs reports on his $\mathrm{PhD}$ research which was part of the 'Wired Up' research project at Utrecht University. This project studied digital media as innovative socialization practices for migrant youth. Leurs' research - resulting in his dissertation, several research articles, and this book - focuses specifically on identity constructions of Moroccan-Dutch youth. In the Netherlands, this group is often confronted with negative group perceptions in society, making them 'non-mainstream users' of digital media. Digital media offer new platforms to socialize and explore various aspects of their identity.

After the introductory chapter in which Leurs introduces his theoretical approaches, the structure of the book is as follows: Chapter 1 provides an elaborate outline of the methodology. Chapters 2 to 5 are empirical chapters analyzing the use of four specific types of online platforms: online forums Marokko.nl and Chaima.nl; the instant messaging tool MSN; social networking sites Hyves and Facebook; and video sharing site YouTube.com. Chapter 6 is the concluding chapter that connects the empirical findings to Leurs' theoretical concepts of 'digital passages' and 'space invaders'.

\section{Digital humanities at its best}

Digital humanities entails researching intersections between new media technologies and social practices. This book can be situated in this relatively new area of research. In chapter 1 , which follows the theoretical introduction, Leurs introduces his data and methodology. He uses a combination of quantitative and qualitative data from the Wired Up project. This comprises a survey among 344 Moroccan Dutch youth, in-depth semi-structured interviews among 48 adolescents, and virtual ethnography of online material that interview respondents shared with him. The chapter underlines the importance of combining online and offline data when

* $\quad$ Rianne Dekker, MSc. is PhD candidate at the Department of Public Administration at Erasmus University Rotterdam. Email: r.dekker@fsw.eur.nl. 
researching online behavior. The survey data provide a short introduction to the popularity of specific online platforms. The semi-structured interviews form the backbone of Leurs' research on which most of the analysis is based. A particularly useful technique is the use of image-based concept mapping (pp. 78-79) to encourage youth to reflect on their online media use. The virtual ethnography enables Leurs to provide more detail and examples of online identity construction by Moroccan-Dutch youth.

Readers looking for a textbook example of studying online media uses will find this in Leurs' methodology chapter (chapter 1). In this chapter he addresses a variety of challenges facing digital humanities scholars, including practical challenges of recruiting respondents in online venues, difficulties respondents face in reflecting on their online practices, translating and interpreting 'slang' in online text, and ethical considerations concerning privacy. Leurs is reflexive toward his position as a researcher and the respondents' positions as users of online media. Central to his methodology is enabling respondents to maintain the boundaries of their digital space. The methodological chapter reads like a novel as Leurs provides honest and recognizable insights into his research experiences.

\section{A cartography of digital identity performativity}

In the empirical chapters 2 to 5 , the analysis is guided by a broad theoretical approach, as Leurs combines theories from feminist, postcolonial, critical geography, new media, and migration studies. Two analogies are central to his analysis: online media as 'digital passages' and Moroccan-Dutch youth as 'digital space invaders'. The concept of 'digital passages' relates to European mid-nineteenth century arcades or passageways that were described by critical theorist Walter Benjamin. Leurs compares online media to these arcades as they fulfil a double role as a place of refuge and commercialism. Also parallel to Benjamin's analysis of the arcades, Leurs concludes that the social dynamics of online media cannot be fully captured by skepticism or evangelism. The concept of 'digital space invaders' builds on Puwar's (2004) research on offline, institutionalized spaces where minorities are 'space invaders' because they are not the somatic norm. Leurs maintains that this also concerns Moroccan-Dutch youth online. Online media are not the anonymous, disembodied spaces that some expect them to be.

The empirical chapters constitute a 'cartography' of digital identity performativity of Moroccan-Dutch youth on four popular online platforms. In thick descriptions, Leurs outlines how diasporic, gender, and cultural aspects of Moroccan-Dutch youth identity interact. Different online platforms fulfil different roles for Moroccan-Dutch youth, analogous to the mid-nineteenth century arcades.

Chapter 2 describes how Moroccan-Dutch youth use discussion forums as 'hush harbors', a notion previously used to describe spaces in which slaves gathered away from supervision from their white masters, where hegemonies can be scrutinized and group cohesion can be fostered. Chapter 3 describes how instant messaging expands 'socio-cultural parameters of action'. Primarily for Moroccan-Dutch girls, 
conflicting gender and sexual norms exist. Chapter 4 analyses performances of gender and ethnicity in hyperlinks and profile pictures shared on Hyves and Facebook. Leurs concludes that digital disembodiment is a myth and Moroccan-Dutch youth combine multiple associations that are sometimes considered to be incompatible (e.g. wearing a headscarf and Dutch nationalism). Chapter 5 analyzes the use of YouTube as the intersection between affectivity and media use over transnational and local space.

Combining multiple theoretical approaches and introducing several new concepts makes for a complex approach to interpret the empirical data. At some points, findings are connected to the theoretical framework more systematically than at other points, and contrasting findings are not always explained. For example, Leurs interprets the use of online media by Moroccan-Dutch youth as subversion of the mainstream dominant morale. However, this is not always supported by the youths' own interpretations and motivations of their online behavior. Multiple empirical examples indicate that the respondents perceive their online uses as trivial ways of killing time (e.g., pp. 93, 106) They do not seem to mind when there is no clear-cut box to tick on social networking sites that fits their ethnic identity (p. 252). This is exemplary of how the gap between Leurs' theoretical approaches and empirical data is sometimes too large to make a convincing argument.

\section{Rich insights but cautious conclusions}

In the concluding chapter, Leurs returns to his theoretical departure point and speaks to the fields of new media, gender, postcolonial studies, migration and transnationalism, religion, media and communication studies, cyber feminism, studies of girlhood, and studies on the Moroccan-Dutch community in particular. Leurs concludes that a mutual constitution of identity and technology takes shape in everyday, situated, and power-laden medium-specific contexts. Most online media reflect norms of mainstream society. While this finding is not new, Leurs contributes to the literature by distinguishing four ways in which Moroccan-Dutch youth are subversive space invaders: by masking of difference, appropriating a space to become the majority, the conveyance of hybridized belongings across Internet applications, and the articulation of hypertextual narratives of selves. By this, Moroccan-Dutch youth go beyond ethnic segregation and perceptions of failed multiculturalism.

Readers from different disciplines will definitely find Digital Passages an interesting read, particularly those researchers with a methodological interest in digital humanities and students of social consequences of online behavior. Yet, Leurs does not offer the reader many ready-made conclusions when it comes to the consequences of online behavior of Moroccan-Dutch youth specifically. His conclusions are often concealed in analogies and metaphors. The impressive theoretical exercise, on the one hand, and rich empirical data, on the other, are not fully brought together. Some explicit research questions and theoretical expectations would have been helpful in focusing the analysis. This, however, should not prevent readers from a 
broad range of disciplines from learning more about online media use by a marginalized group, or to learn from a textbook example of qualitative methods for digital humanities.

\section{References}

Puwar, N. (2004). Space invaders: Race, gender and bodies out of place. Oxford, UK: Berg. 